\title{
ОЦІНКА ТЕХНІКИ ГОДІВЛІ СЛУЖБОВИХ СОБАК В УМОВАХ НАВЧАЛЬНОЇ ЛАБОРАТОРІЇ КІНОЛОГІЇ ПОЛІСЬКОГО НАЦІОНАЛЬНОГО УНІВЕРСИТЕТУ
}

\author{
Мамченко Віталій Юрійович \\ кандидат сільськогосподарських наук \\ Поліський національний університет \\ ORCID: 0000-0002-7208-6363 \\ E-mail: 79mamchenko@gmail.com
}

Лавринюк Оксана Олексадрівна кандидат сільськогосподарських наук Поліський національний університет ORCID: 0000-0003-3145-3689 E-mail: oksana_lavren@ukr.net

Вечорка Вікторія Вікторівна доктор сільськогосподарських наук, просресор Сумський національний аграрний університет ORCID: 0000-0003-4956-2074

E-mail: vvvechorka@gmail.com

У статті наведена оцінка техніки годівлі службових собак в умовах навчальної лабораторії кінології Поліського національного університету. Аналізуючи звіти лабораторії кінології, слід відмітити, що кількість та породний склад собак за останні 3 роки поступово збільшується і на кінець 2020 року становить: Німецька вівчарка - 10 голів, Середньоазіатська вівчарка - 4, Лабрадор - 4, Самоїд -2, Далматинець - 1 голова. Основу раціону для службових собак займають корми тваринного походження (субпродукти, м'ясо, молоко та молочні продукти, жир тваринний), рослинного походження (крупа вівсяна, ячмінна, пшоно, овочі), морська риба або морепродукти, мінеральні добавки (кісткове борошно, сіль кухонна), вітамінні препарати (тетравіт, катозал). В умовах навчальної лабораторії собаки харчуються двічі на добу ураниі і у вечері, приблизно за 1,5 години до виконання службових обов'язків і через 30-60 хвилин після роботи. Годівля собак залежить від розпорядку доби. Собакам, які охороняють територію у нічні часи годування проводять за 80-120 хвилин до роботи, а зранку після того, як їх зняли з охорони після відпочинку. Напування службових собак без обмежень. Результати дослідження крові доводять нам про те, що всі фізіологічні процеси в організмі тварин відбуваються нормально, без відхилень. При розрахунках економічної ефектиивності наведені дані говорять про те, що витрати на раціони годівлі тварин у періоді спокою на 2115 гривень менші, ніж у собак, які виконують службові обов'язки. Це пояснюється тим, що тварини, які залучені на охорону об'єктів, територій, витрачають значно більше енераії та потребують підвищену потребу у поживних речовинах (м'ясо, риба).

Ключові слова: німецька вівчарка, техніка годівлі, службові собаки, утримання, раціон, м'ясо, риба, крупа, добавки, показники крові, економічна ефективність.

DOI: https://doi.org/10.32845/bsnau.lvst.2021.2.15

Уже досить багато років німецька вівчарка $є$ найпопулярнішою породою в Європі. Популярність даної породи можна пояснити тим, що ця собака універсальна: робоча, спортивна, охоронна, поводир або просто хороший друг. Крім того, вона легко пристосовується до будь-яких умов. Дуже витривала, проте потребує правильного догляду та харчування [1,2].

Німецька вівчарка - розумна, безстрашна тварина $з$ дуже міцними щелепами. Вона відповідальна, хоробра та ідеальна для службового собаківництва [3,4].

Історія породи нараховує не одну сотню років. Предками німецьких вівчарок були, можливо, перші собакипастухи та фермерські собаки. Довгий час порода формувалася стихійно. В основному собак утримували пастухи. Вони відбирали собак з найкращими робочими якостями. В даний час не існує документів, які свідчать про становлення породи. Як в минулому, так і тепер німецькі вівчарки вважаються найрозумнішими собаками $[5,6]$.

Німецькі вівчарки - безстрашні і мужні собаки. Вони впевнені у своїх силах, дуже розумні, насторожені і зосере-

джені. Вони легко піддаються дресируванню. Його найкраще розпочинати у ранньому віці [7].

Найціннішими якостями чистопородної німецької вівчарки $€$ сильний тип нервової діяльності, уважність, слухняність, вірність і непідкупність, а також сміливість, бойовий інстинкт і злобність. Ці якості роблять ії дуже цінною собакою в цілому, і особливо добре пристосованою до виконання караульних, охоронних, захисних і супроводжуючих завдань. У цих собак добре розвинутий нюх, вони без перенапруги спокійно ідуть по сліду, опускаючи ніс майже до землі, це робить їх придатними і для пошукової та іншої роботи [8].

Враховуючи вище зазначене, метою наших досліджень $€$ оцінка техніки годівлі та утримання службових собак в умовах навчальної лабораторії кінології Поліського національного університету.

Матеріали та методи дослідження. Матеріалом досліджень були службові собаки породи німецька вівчарка, звіт навчальної лабораторії кінології, процеси, що використовуються під час годівлі, утримання, роздавання кормів, водонапування. При написанні статті використовували ана- 
літичні, зоотехнічні, біохімічні та розрахункові методи досліджень за загально прийнятими методиками.

Результати дослідження. Кормовий раціон для службових собак в умовах навчальної лабораторії кінології розробляють згідно норм, обов'язково при цьому враховують навантаження на собаку. У таблиці 1 наведені корми та добові витрати, які становлять основу раціону для службових собак в умовах навчальної лабораторії кінології.

Таблиия 1

Витрати кормів для службових собак

\begin{tabular}{|c|c|}
\hline Назва корму & Кількість, г \\
\hline \multicolumn{2}{|c|}{ Тваринного походження: } \\
\hline м'ясо 2 категорії (яловичина, конина) & $300-500$ \\
\hline суб. продукти & $400-600$ \\
\hline молоко, сироватка & $200-500$ \\
\hline жир тваринний & $15-25$ \\
\hline жир риб'ячий & $15-25$ \\
\hline \multicolumn{2}{|c|}{ Рослинного походження: } \\
\hline крупа вівсяна & $300-600$ \\
\hline крупа ячмінна & $300-600$ \\
\hline Пшоно & $300-600$ \\
\hline морква, картопля, буряк, зелень & 200 \\
\hline \multicolumn{2}{|l|}{ Мінеральні добавки: } \\
\hline кісткове борошно & $15-25$ \\
\hline сіль кухонна & $15-25$ \\
\hline \multicolumn{2}{|c|}{ Вітамінні препарати: } \\
\hline тетравіт & 1 мл на 10 кг ваги \\
\hline катозал & 1 мл на 10 кг ваги \\
\hline \multicolumn{2}{|l|}{ Інші корми: } \\
\hline риба морська & $200-500$ \\
\hline
\end{tabular}

Як видно з даної таблиці основу раціону для службових собак займають корми тваринного походження (субпродукти, м'ясо, молоко та молочні продукти, жир тваринний), рослинного походження (крупа вівсяна, ячмінна, пшоно, овочі), морська риба або морепродукти, мінеральні добавки (кісткове борошно, сіль кухонна), вітамінні препарати (тетравіт, катозал).

Слід відмітити, що при відсутності м'яса його замінюють або субпродуктами або морепродуктами, або дають по 50\% м'яса та риби. 3 використаних кормів собакам готують м'ясні супи. Молочні продукти дають окремо не більше двох разів на добу.

У таблиці 2 наведений раціон годівлі для службових собак у період виконання службових обов'язків.

Як видно з даної таблиці основу раціону складають корми тваринного походження (м'ясо яловичини 2 категорії, риба морська), а також корми рослинного походження (крупа вівсяна, картопля, морква, буряк) та добавки (сіль кухонна, риб'ячий жир, кісткове борошно), вітамінний препарат тетравіт (усунення дефіциті вітамінів $B_{1}$ та $B_{2}$ та катозал, якій використовують для профілактики та лікування вірусних інфекцій: парвовірус, коронавірус, аденовірус, чума. Лікування та профілактика бактеріальних інфекцій. Гострі гельмінтози. Кровопаразитарні хвороби: піроплазмоз (бабезіоз), гемобартонелльоз, ерліхіоз, анаплазмоз. Захворювання шкіри: атиповий дерматит, демодекоз, лишай, хвороби рухового апарату.

Слід відмітити, що у раціоні для собак при виконанні службових обов'язків не вистачає легкоперетравних вуглеводів (- 65,4 г), а також сирої клітковини (-14,3 г) та вітаміну А (-504 мг). Всі інші показники знаходяться у межах допустимих норм. Даванка корму складала - 1451 грам. 
Раціон годівлі службових собак у період виконання службових обов'язків,

\section{ж. м. 40 кг}

\begin{tabular}{|c|c|c|c|c|c|c|c|c|c|c|}
\hline \multirow[b]{2}{*}{ Склад раціону } & \multirow[b]{2}{*}{$\begin{array}{c}\text { К-ть } \\
\text { корму, г }\end{array}$} & \multicolumn{9}{|c|}{ Міститься в раціоні } \\
\hline & & $\begin{array}{c}\text { енергія, } \\
\text { кДж }\end{array}$ & $\begin{array}{c}\text { білок, } \\
\text { г }\end{array}$ & жир, г & $\begin{array}{c}\text { легкоперетравні } \\
\text { вуглеводи, г }\end{array}$ & $\begin{array}{c}\text { клітковина, } \\
\text { г }\end{array}$ & $\mathrm{Ca}, \mathrm{r}$ & $P, r$ & $\begin{array}{l}\text { Віт. } \\
\text { А, мг }\end{array}$ & $\begin{array}{l}\text { Віт. } \\
\text { Д, мг }\end{array}$ \\
\hline \multicolumn{2}{|l|}{ Норма } & 9165 & 203 & 45 & 363 & 24 & 105,6 & 88,0 & 4000 & 280 \\
\hline м'ясо яловичини 2 категорія & 300 & 1806 & 60,6 & 21 & - & - & 8,7 & 9,6 & 2100 & 9 \\
\hline крупа вівсяна & 400 & 5776 & 47,6 & 23,2 & 261,6 & 6,8 & 10,8 & 9,2 & 376 & 44 \\
\hline картопля & 70 & 300 & 2 & 0,1 & 19,7 & 1 & 0,7 & 4,8 & - & - \\
\hline морква & 70 & 106 & 1,1 & 0,1 & 6 & 1 & 3,9 & 4,2 & 420 & - \\
\hline буряк столовий & 60 & 120 & 1,2 & - & 9,8 & 0,9 & 2,3 & 3,2 & - & - \\
\hline риба морська & 500 & 1360 & 86,5 & 33,5 & - & - & 50,5 & 43 & 50 & 20 \\
\hline сіль кухонна & 15 & - & - & - & - & - & - & - & $=$ & - \\
\hline риб'ячий жир & 15 & 420 & - & 15 & - & - & 1 & 1,2 & 600 & 200 \\
\hline кісткове борошно & 15 & 225 & 5,1 & 2,1 & 0,5 & - & 32 & 20 & - & - \\
\hline 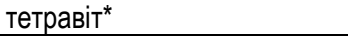 & $3 \mathrm{Mг}$ & - & - & - & - & - & - & - & - & - \\
\hline катозал* & 3 мл & - & - & - & - & - & - & - & - & - \\
\hline Всього міститься в раціоні & 1451 & 10113 & 204,1 & 95 & 297,6 & 9,7 & 109,9 & 95,2 & 3496 & 273 \\
\hline 士 до норми & - & +948 & $+1,4$ & +50 & $-65,4$ & $-14,3$ & $+4,3$ & $+7,2$ & -504 & -7 \\
\hline
\end{tabular}

*Teтравіт (1 таблетка містить 3 мг вітаміну $B_{1}$ та 3 мг вітаміну $B_{2}$ ).

*Катозал - містить у складі бутафосфран - 10 г на фрлакон 100 мл;

Ціанокобаламін (вітамін $\mathrm{B}_{12}$ ) - 5 мг. Показання: Вірусні інфекції:парвовірус, коронавірус, аденовірус, чума. Бактериальні інфекції. Гострі гельмінтози. Кровопаразитарні хвороби: піроплазмоз (бабезіоз), гемобартонелльоз, ерліхіоз, анаплазмоз. Захворювання шкіри: атиповий дерматит, демодекоз, лишай, хвороби рухового апарату.

У таблиці 3 наведений раціон годівлі службових собак у період спокою, жива маса - 30 кг.

Таблиця 3

Раціон годівлі службових собак у період спокою, ж.м. 30 кг

\begin{tabular}{|c|c|c|c|c|c|c|c|c|c|c|}
\hline \multirow[b]{2}{*}{ Склад раціону } & \multirow[b]{2}{*}{ К-ть корму, г } & \multicolumn{9}{|c|}{ Міститься в раціоні } \\
\hline & & \multirow{2}{*}{$\begin{array}{c}\begin{array}{c}\text { енергія, } \\
\text { кДж }\end{array} \\
6900 \\
\end{array}$} & \multirow{2}{*}{$\begin{array}{c}\text { білок, г } \\
135 \\
\end{array}$} & \multirow{2}{*}{$\begin{array}{c}\text { жир, г } \\
39,2 \\
\end{array}$} & \multirow{2}{*}{$\begin{array}{c}\begin{array}{c}\text { легкоперетравні } \\
\text { вуглеводи, г }\end{array} \\
279 \\
\end{array}$} & \multirow{2}{*}{$\begin{array}{c}\text { клітковина, } \\
\text { г }\end{array}$} & \multirow{2}{*}{$\begin{array}{l}\text { Ca, r } \\
79,2\end{array}$} & \multirow{2}{*}{$\begin{array}{l}\mathbf{P}, \mathbf{r} \\
66,0\end{array}$} & \multirow{2}{*}{$\begin{array}{c}\begin{array}{c}\text { Biт. A, } \\
\text { Mr }\end{array} \\
3000\end{array}$} & \multirow{2}{*}{$\begin{array}{c}\begin{array}{c}\text { Biт. A, } \\
\text { Mr }\end{array} \\
210\end{array}$} \\
\hline Норм & & & & & & & & & & \\
\hline серце & 200 & 728 & 30,4 & 6,4 & 5,4 & - & 1,4 & 21 & 900 & 32 \\
\hline легені & 200 & 770 & 29 & 7,0 & 4 & - & 2,1 & 9,8 & 700 & 24 \\
\hline молоко & 300 & 260 & 9 & 9,6 & 14,1 & - & 14,8 & 5,8 & 300 & 30 \\
\hline крупа ячмінна & 300 & 2692 & 31,2 & 3,9 & 215,1 & 4,2 & 12,6 & 10,2 & 475 & - \\
\hline картопля & 50 & 173 & 1 & 0,1 & 9,9 & 1 & 0,7 & 2,9 & - & - \\
\hline морква & 60 & 74 & 0,8 & 0,1 & 4 & 1 & 3,8 & 4,2 & 420 & - \\
\hline буряк столовий & 60 & 112 & 0,9 & - & 7,1 & 0,9 & 2,3 & 3,2 & - & - \\
\hline риб'ячі голови & 200 & 960 & 29,4 & 14,4 & - & - & 5,4 & 4 & 100 & 40 \\
\hline сіль кухонна & 15 & - & - & - & - & - & - & - & - & - \\
\hline риб'ячий жир & 15 & 420 & - & 15 & - & - & 1 & 1,2 & 600 & 200 \\
\hline кісткове борошно & 15 & 225 & 5,1 & 2,1 & 0,5 & - & 32 & 20 & - & - \\
\hline тетравіт ${ }^{*}$ & $3 \mathrm{Mr}$ & - & - & - & - & - & - & - & - & - \\
\hline катозал ${ }^{*}$ & 3 мл & - & - & - & - & - & - & - & - & - \\
\hline $\begin{array}{l}\text { Всього міститься } \\
\text { в раціоні }\end{array}$ & 1421 & 6414 & 136,8 & 58,6 & 260,1 & 7,1 & 76,1 & 82,3 & 3065 & 326 \\
\hline \pm до норми & - & -486 & $+1,8$ & $+19,4$ & $-18,9$ & $-16,9$ & $-3,1$ & $+16,3$ & +65 & +116 \\
\hline
\end{tabular}

У раціоні не вистачає енергії - 486 кДж, клітковини 16,9 г. Всі інші показники у межах допустимих норм. Даванка корму складала - 1421 грам.
У таблиці 4 наведений раціон годівлі собак службових порід у другій половині вагітності. 
Таблиця 4

Раціон годівлі службових собак (самки у другій половині вагітності), ж.м. 30 кг

\begin{tabular}{|c|c|c|c|c|c|c|c|c|c|c|}
\hline \multirow[b]{2}{*}{ Склад раціону } & \multirow[b]{2}{*}{ К-ть корму, г } & \multicolumn{9}{|c|}{ Міститься в раціоні } \\
\hline & & \multirow{2}{*}{\begin{tabular}{|c|} 
енергія, \\
кДж
\end{tabular}} & \multirow{2}{*}{$\begin{array}{c}\text { білок, г } \\
188 \\
\end{array}$} & \multirow{2}{*}{$\begin{array}{c}\text { жир, г } \\
35,8\end{array}$} & \multirow{2}{*}{$\begin{array}{c}\begin{array}{c}\text { легкоперетравні } \\
\text { вуглеводи, г }\end{array} \\
279\end{array}$} & \multirow{2}{*}{$\begin{array}{c}\begin{array}{c}\text { клітковина, } \\
\text { r }\end{array} \\
20 \\
\end{array}$} & \multirow{2}{*}{$\frac{\mathrm{Ca}, \mathrm{r}}{105,6}$} & \multirow{2}{*}{$\begin{array}{c}\mathbf{P}, \mathbf{r} \\
88\end{array}$} & \multirow{2}{*}{$\begin{array}{c}\text { Віт. А, мг } \\
4000\end{array}$} & \multirow{2}{*}{$\begin{array}{c}\begin{array}{c}\text { Biт. A, } \\
\text { мг }\end{array} \\
280\end{array}$} \\
\hline Норма & & & & & & & & & & \\
\hline $\begin{array}{l}\text { м'ясо яловичини } 2 \\
\text { категорія }\end{array}$ & 400 & 2408 & 80,8 & 28 & - & - & 40 & 15,2 & 2500 & 15 \\
\hline молоко незбиране & 300 & 729 & 8,4 & 9,6 & 14,1 & - & 36,6 & 5,8 & 300 & 30 \\
\hline крупа вівсяна & 400 & 5776 & 47,6 & 23,2 & 261,6 & 6,8 & 10,8 & 9,2 & 376 & 44 \\
\hline картопля & 50 & 175 & 1 & 0,1 & 9,9 & 1 & 0,7 & 2,9 & - & - \\
\hline морква & 50 & 70 & 0,7 & 0,1 & 3,5 & 1 & 3,4 & 3,9 & 400 & - \\
\hline буряк столовий & 50 & 102 & 0,8 & - & 5,4 & 0,7 & 2 & 2,8 & - & - \\
\hline риба морська & 200 & 900 & 31 & 10 & - & - & 54 & 45 & 70 & 40 \\
\hline сіль кухонна & 15 & - & - & - & - & - & - & - & - & - \\
\hline тваринний жир & 25 & 800 & 0,1 & 19,5 & - & - & 1,4 & 1,7 & 650 & 220 \\
\hline кісткове борошно & 20 & 235 & 5,2 & 17 & 0,7 & - & 13 & 22 & - & - \\
\hline тетравіт* & $3 \mathrm{Mr}$ & - & - & - & - & - & - & - & - & - \\
\hline катозал" & 3 мл & - & - & - & - & - & - & - & - & - \\
\hline $\begin{array}{l}\text { Всього міститься в } \\
\text { раціоні }\end{array}$ & 1416 & 11195 & 175,6 & & 294,8 & 9,5 & 161,9 & 93,5 & 4296 & 349 \\
\hline \pm до норми & & +535 & $-12,4$ & $+71,5$ & $+15,8$ & $-10,5$ & $+56,3$ & $+5,5$ & +296 & +69 \\
\hline
\end{tabular}

У раціоні відмічається надлишок енергії - 535 кДж, жиру - 71,5 г, кальцію - 56,3 г, недостатня кількість - клітковини - 10,5 г. Разова даванка корму становить - 1416 грамів на голову на добу.

Для більш точної деталізації фрізіологічного стану службових собак, наші дослідження доповнювали показниками крові (гематологічні, біохімічні). Перед постановкою на дослідження всі собаки були клінічно здорові.

Кров відбирали до ранкової годівлі у заключній стадії

проведення досліджень.

У таблиці 5 наведені показники крові собак німецької вівчарки.

Результати дослідження крові свідчать про те, що всі фізіологічні процеси в організмі тварин відбуваються нормально, без відхилень. Це свідчить про те, що годівля службових собак в умовах навчальної лабораторії кінології Поліського національного університету відбувається згідно деталізованих норм і фізіологічних потреб собак.

Таблиця 5

Показники крові собак ( $\mathrm{n}=6)$

\begin{tabular}{|l|c|c|}
\hline \multicolumn{1}{|c|}{ Показники } & Фізіологічна норма & Фактичний вміст \\
\hline гемоглобін г/л & $120-180$ & $158,2+\underline{3}, 61$ \\
\hline еритроцити Т/л & $5,5-8,5$ & $5,9 \pm 0,31$ \\
\hline лейкоцити г/л & $6-15$ & $7,7 \pm 0,52$ \\
\hline тромбоцити Т/л & $200-500$ & $410+19,0$ \\
\hline ШОЕ мм/г & $0-4$ & $2,1+0,33$ \\
\hline глюкоза моль/л & $3,5-5,5$ & $4,0+0,23$ \\
\hline Са моль/л & $2,24-2,95$ & $2,68+0,11$ \\
\hline Р моль/л & $1,45-1,94$ & $1,39+0,08$ \\
\hline заг. білок г/л & $54-80$ & $57,61+0,38$ \\
\hline
\end{tabular}

Висновки. 1. Навчальна лабораторія кінології Поліського національного університету знаходиться у місті Житомир. Юридична адреса - вулиця Корольова 39.

2. Основу раціону для службових собак займають корми тваринного походження (субпродукти, м'ясо, молоко та молочні продукти, жир тваринний), рослинного походження (крупа вівсяна, ячмінна, пшоно, овочі), морська риба або морепродукти, мінеральні добавки (кісткове борошно, сіль кухонна), вітамінні препарати (тетравіт, катозал).

3. В умовах навчальної лабораторії собаки харчу- ються двічі на добу - уранці і у вечері, приблизно за 1,5 години до виконання службових обов'язків і через 30-60 хвилин після роботи. Годівля собак залежить від розпорядку доби. Собакам, які охороняють територію у нічні часи годування проводять за 80-120 хвилин до роботи, а зранку після того, як їх зняли з охорони після відпочинку. Напування службових собак без обмежень.

4. Результати дослідження крові свідчать нам про те, що всі фізіологічні процеси в організмі тварин відбуваються нормально, без відхилень.

\section{Список використаної літератури:}

1. Арасланов Ф. С. Захисно-вартова служба. М.: МНПО «Ера», 1992 . 45 с.

2. Аркадьєва Н. Г. Лікування собак: Довідник ветеринара М.: ТОВ Видавничий дім «Віче», 2007. 176 с.

3. Богданова І. Б. Харчування кішок і собак. М.: ТОВ «Гамма Прес 2000», 2002. 416 с.

4. Букатевич Ю. В. Собаківництво. К.: 1993. с. 34-46.

5. Бурлака В. А., Павлюк, Н. В., Степаненко В. М. Кінологія: утримання та годівля собак, навчальний посібник Ж: Волинь 2004 р. 183 с.

6. Вибір і виховання щеняти. Вид-во Дельта, 2001. 224 с. 
7. Гельмут М., Юрген 3. Кормление собаки. / Пер. с нем. Захаров Е. М.: «Аквариум», 1998. 144с., ил.144с.

8. Герхард Шюлер. Служебное собаководство. М.: 1999 г. С. 54-63.

\section{References:}

1. Araslanov F. S., 1992. Security guard service. M .: MNPO "Era", $45 \mathrm{~s}$.

2. Arkadyeva N. G., 2007. Treatment of dogs: Handbook of veterinarian M .: LLC Publishing House "Viche", 176.

3. Bogdanova I. B. Nutrition of cats and dogs. M .: Gamma Press 2000, 2002. 416 p.

4. Bukatevich Yu. V. 1993. Dog breeding. K. pp. 34-46.

5. Burlaka V. A., Pavlyuk, N. V., Stepanenko V. M., 2004. Cynology: keeping and feeding dogs, textbook Zh .: Volyn, 183.

6. Choosing and raising a puppy, 2001. Delta Publishing House, 224.

7. Helmut M., Jürgen Z., 1998. Feeding the dog. Per. with him. Zakharov EM: "Aquarium", 144.

8. Gerhard Schuler., 1999. Service dog breeding. M . pp. 54-63.

Mamchenko Vitaliy Yuriyovych, Candidate of Agricultural Sciences

Lavryniuk Oksana Oleksandrivna, Candidate of Agricultural Sciences

Polissya National University (Zhytomyr, Ukraine)

Vechorka Victoria Viktorivna, Doctor of Agricultural Sciences, Professor

Sumy National Agrarian University (Sumy, Ukraine) national university

Evaluation of feeding techniques of service dogs in the conditions of the training laboratory of cynology of polish

The article evaluates the technique of feeding service dogs in the training laboratory of cynology of Polissya National University. Analyzing the reports of the cynology laboratory, it should be noted that the number and breed composition of dogs over the past 3 years is gradually increasing and at the end of 2020 is: German Shepherd - 10 heads, Central Asian Shepherd - 4, Labrador 4, Samoyed - 2, Dalmatian - 1 head. The basis of the diet for service dogs are animal feed (offal, meat, milk and dairy products, animal fat), vegetable origin (oatmeal, barley, millet, vegetables), sea fish or seafood, mineral supplements, bone meal, salt kitchen), vitamin preparations (tetravit, katozal). In the training laboratory, dogs are fed twice a day - in the morning and in the evening, about 1.5 hours before work and 30-60 minutes after work. Feeding dogs depends on the daily routine. Dogs guarding the area at night are fed 80-120 minutes before work, and in the morning after being removed from guard after rest. Watering service dogs without restrictions. The results of blood tests prove to us that all physiological processes in the body of animals occur normally, without deviations. In terms of cost-effectiveness calculations, the data suggest that the cost of feeding animals at rest is 2,115 hryvnias lower than that of dogs on duty. This is due to the fact that animals that are involved in the protection of objects, areas, consume much more energy and need an increased need for nutrients (meat, fish).

Key words: German shepherd, feeding technique, service dogs, content, diet, meat, fish, cereals, supplements, blood indicators, economic efficiency.

Дата надходження до редакції: 06.05.2021 р. 